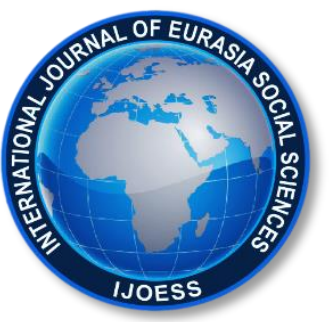

International Journal of Eurasia Social Sciences

Vol: 11, Issue: 39, pp. (11-22).

Article Type: Research Article

Received: 24.07.2019 Accepted: 19.03.2020

\title{
THE ROLE OF COMMITMENT TO LEARNING IN THE EFFECT OF EVALUATION AND REWARDS ON PROJECT SUCCESS IN R\&D TEAMS
}

\author{
Mehmet Saim AŞÇı \\ Dr., Istanbul Medipol University, Turkey, msasci@medipol.edu.tr \\ ORCID: 0000-0001-5508-2267 \\ Mustafa Emre CIVELEK
}

Assoc. Prof. Dr., Istanbul Commerce University, Türkiye, ecivelek@ticaret.edu.tr ORCID: 0000-0002-2847-5126

Murat ÇEMBERCi

Assoc. Prof. Dr,, Yıldız Technical University, Türkiye, cemberci@yildiz.edu.tr ORCID: 0000-0001-8569-4950

\begin{abstract}
In enterprises, Research and Development (R\&D) activities are carried out on the basis of projects. R\&D projects are conducted by teams of employees from the different departments in an enterprise. Members of R\&D teams have different competencies, and the most prominent features are that they are creative and learning-oriented. Despite the competencies of the employees, it is very difficult to manage such teams successfully. Keeping the motivation of team members high and managing the team in a success-oriented way require important managerial skills since such teams have many different sources of motivation. Therefore, team leaders need to identify the factors that will lead their R\&D teams to success. Accordingly, this paper attempts to explain the role of commitment to learning on the relationship between evaluation-rewards and project success. The mediator analyses were conducted according to the methodology suggested by Baron and Kenny. As a result of the hypothesis tests, it has been found out that commitment to learning has a mediator effect on the relationship between evaluation and reward and project success. In R\&D teams, team members' commitment to learning is critical to the impact of reward and evaluation on project success. Therefore, the leaders who will lead these teams need to consider the nature of an adhocratic organization while taking into account the factors that will influence team success.
\end{abstract}

Keywords: Commitment to learning, evaluation and rewards, project success, team working, R\&D teams 


\section{INTRODUCTION}

R\&D teams are known to be fragile teams that may at times be jealous and or unpopular, often not recognized by other organisation's departments. R\&D teams can take indiscriminate initiatives. R\&D teams are the pioneers of the change as Alvin Toffler (1970) stated in his statement: "The faster the environment changes, the shorter the life span of organizational structures". In administrative constructs like, architectural structures, we observe a movement from long-standing structures to temporary structures, from continuous to temporary. In other words, the transition from bureaucracy to adhocracy is observed. Adhocracy is a concept that was put forward by Warren Bennis (1975). It has later been developed in the works of Alvin Toffler and introduced worldwide. Adhocracy is a form of organization in which roles of each person are determined in such a way that classical principles of bureaucracy are ignored. Adhocracy in a sense refers to the opposite of bureaucracy. Such constructs are usually structures that are installed to perform a specific task and disintegrate when the process ends. Adhocratic structures are temporary organizational structures with high ability to change. While environmental conditions change rapidly, organizations need to respond faster and more flexibly than ever before. H. Mintzberg (1969) defined adhocracy as expert-based organic structures which do not pay much attention to the classical principles of governance. Adhocracy refers to structures where formality is very limited, flexible working conditions are provided to its experts and unrestricted coordination channels. In these structures, educated and expert persons exist who are capable of self-management and supervision work. In adhocratic administration, it is preferable to focus on individual projects and outcomes rather than adopting a holistic approach. Talent and vocational training come to the forefront in such organizations. Unlike bureaucracy, titles of people remain in the background. Adhocratic structures are rigid, not rigid, but easy to adapt. They are characterized by temporary task groups and organizations, which increases the likelihood of the organization to innovate and invent, reducing the organizational culture that hinders change, or in other words, supporting the drive to hide behind organizational secrets and rules in a conventional way. In short, adhocratic structures transform inherent energies into creativity while traditional organizations spend their energies in vain for bureaucracy. This does not mean that adhocratic organizations do not have any structures, but unlike many other organizations, organizational structures and cultures allow people to remove barriers against business (Çemberci, 2012: 71).

Since people generally think of $R \& D$ as computers, spacecraft, cars and similar products, it is normal to use terms such as "scientists" and "engineers" to describe the experts of these organizations. Yet, there are other experts in these organizations. Programmers, psychologists, personnel experts, writers, artists and clients are also involved in R\&D teams (Miller, 1986: 133). Traditionally, when R\&D teams are considered, members of the team work together, sit close to each other, that is, they are close to each other in terms of physical location, often communicate with each other, and perform design tasks face to face and together. R\&D teams are made up of people who want to be self-motivated and managed in the right business environment. They are successoriented and want to contribute. They are the driving force of progress and are the inventors of creative ideas. Leaders in R\&D teams are generally well-educated on technical level and their contributions in technical fields 
are outstanding (Miller, 1986: 147). Managing such an organization is not only about science and technology, but also about interpersonal relationships and how to manage people. However, this combination is rare in $R \& D$ specialists because the second requirement is not normally supported by their training.

In addition, they worked for a long time to give importance to technical aspects. For this reason, while all organizations complain about the lack of leadership and effective management, R\&D organizations probably feel the lack of understanding of human beings of leadership more than others. The impact of this shortcoming is serious because these engineers, scientists and programmers produce product processes and services that make our lives easier and thus raise our standards. Therefore, these people need to be well managed. If management and leadership in R\&D organizations are improved, a mighty reserve power, which is hidden within people, can emerge. There are also good managers and leaders in R\&D teams that balance technical and humanitarian importance. In good leaders, the elements they work with have some features they are not aware of. At the same time, this process sometimes encourages employees. These leaders have completed the technical developments and are also very assertive and successful in managing human resources. It reveals the fact that engineers working under the targets they have set must constantly renew themselves. If such good characteristics are passed on to others, a positive impact will be created throughout the R\&D organization. $R \& D$ activities are carried out on the basis of projects in enterprises. R\&D projects are conducted by teams of employees from the different departments in an enterprise. Members of R\&D teams have different competencies, and the most prominent features are that they are creative and learning-oriented. It is very difficult to manage such teams in a successful way despite the competencies of the employees. Keeping the motivation of team members high and managing the team in a success-oriented way require important managerial skills since such teams have many different sources of motivation. Hence, team leaders need to identify the factors that will lead their R\&D teams to success. This paper attempts to explain the role of commitment to learning on the relationship between evaluation-rewards and project success. The hypothesis tests have revealed that commitment to learning has a mediator effect on the relationship between evaluation and reward and project success.

\section{CONCEPTUAL BACKGROUND}

\section{Commitment to Learning}

R\&D teams are groups that combine their individual and organizational backgrounds for a narrow period of time and work in close cooperation to market, develop, design and create new products. One of the most important success factors in R\&D teams is that the knowledge that has been obtained by individuals within the team overcomes individual intelligence and this becomes a collective entity that helps the team fulfill its mission (Grant, 1996: 111; Moorman\&Miner, 1997: 6). Realizing and explaining the processes, procedures, creation, sharing, dissemination and use of information in R\&D teams is a critical reason for understanding the success of R\&D teams. In R\&D teams, the learning event requires a serious understanding of the learning process and an extension of its impact on project outcomes (Akgün et al., 2005: 218). In the literature, 
theoretical and experimental studies also show that students have positive effects on project success. Again, in the related literature, Moorman (1995) stated that sense-making correlates positively with R\&D performance (Moorman, 1995: 330). Likewise, Moorman and Miner (1998) note that superior creativity of short-term financial new product performance will positively be stated that the performance (Moorman\&Miner, 1998: 701). These researchers have shown in another study that under highly uncertain environmental conditions, team improvisation has positive effects on the technical performance efficiency of the product (Moorman \& Miner, 1998,: 711). Lynn et al. (2000), having worked on 281 R\&D projects, showed that information acquisition and information application affect R\&D success positively. Cooper (1987) argued that dissemination of information is the foundation of R\&D success (Cooper, 1987: 220).

The degree of commitment to learning or the value that an organization gives to learning is expected to be nurtured within the learning climate. The affiliated organization sees learning as an important investment which is essential to survival. If an organization values learning more, then it is expected that more learning will take place. More notably, commitment to learning is about a long-term strategic tendency. Short-term investments will produce gains in the long-term. For instance, managers of affiliated organizations expect their employees to use company time to track, search, or track information outside of their current business. If an organization does not encourage or encourage knowledge development, employees will not have the motivation to monitor or follow the learning activity (Calantone et al., 2001: 520).

\section{Evaluation and Rewards}

There are various types of teams. And yet, the differences between these teams should be determined well. The main difference between the teams is to be a working group and a regular team. A workgroup includes a group of employees who work together to carry out some tasks. Members in a working group share a common goal and are managed by a leader; however, their performance is considered to be an outcome of their individual efforts. The team is composed of a small number of members with common goals and objectives as well as complementary skills (Katzenbach \& Smith, 1993: 115). The team is a part of the organization. Therefore, the success of the team affects the organization's overall success (Lawler, 1986: 257). The prerequisite for evaluating teamwork is to define team success. Many of the evaluation scales in the literature focus on the internal dynamics of the team and try to explain the relationship between these dynamics and success criteria (Levi \& Slem, 1995: 36). In the extant literature, the definition of team success is the task performance of that team. The performance of successful teams is higher than the individual performance of the members. It is not easy to measure team performance because there may not always be a certain way of evaluating performance for jobs that require creativity (Orsburn et al., 1990: 98). It is essential to establish a reward and evaluation system in order to increase the commitment of the members and focus on success (O'Dell, 1989: 41). This award and evaluation system depends on the success of the team and its members. This is important to provide feedback on the performance of both the members and the team (Hirschhorn, 1991: 101). 


\section{Project Success}

The favourite word of the project implementers is "success" (Howsawi et al, 2014: 6). We can talk about two success concepts in R\&D projects. The first is project success and the other one is project management success. There are differences and similarities between these two dimensions of success (De Wit, 1988: 166; Shenhar, 2007: 96). The main difference is related to the correlation of project success with the assessment of overall project objectives achievement; whereas project management success is related to traditional time, cost and quality performance measures (De Wit, 1988: 168; Cooke-Davies, 2002: 188; Jugdev \& Müller, 2005: 25; Ika, 2009: 11). Yet, owing to the presence of many different models of project and project management success, it is difficult to generate a strong distinction between them, mostly due to their mutual relationship. For the success of project teams right people, structure, and resources are necessary (Christensen, Raynor, Dy \& Gregersen, 2011). Team success can be evaluated by timeliness, costs, quality and outcomes (Zhang, Shen, Zhang \& Zhang, 2015).

Although there is not any consensus regarding the definition of project success (Ika, 2009: 11; McLeod et al, 2012: 72), the researchers agree that project success can be attained through the good actions of the project manager. Project management involves the planning, organization, monitoring and control of all aspects of the project. In this regard, the project manager is not only responsible for time, cost and quality management, but is also responsible for integration, scope, human resources, communication, risk and supply management, and thus for project success. Considering all these factors, how can the success of project management be measured? The success of project management can be assessed based on the time, cost, quality, scope, resource and activity criteria (Kerzner, 2011: 101) as well as the measurement success models such as PMPA Project Management Performance Assessment or maturity models of management within the organization. The question of project management success is difficult to be answered precisely because project management creates both tangible and intangible benefits (Thomas \& Mullaly, 2014: 208). In this study, the project success scale adapted by Çemberci (2012) was used as the project success scale (Çemberci, 2012: 91).

\section{RESEARCH MODEL AND HYPOTHESIS}

The conceptual research model shown in Figure 1 aims to explore the role of commitment to learning in the relationship between evaluation and rewards and project success. 


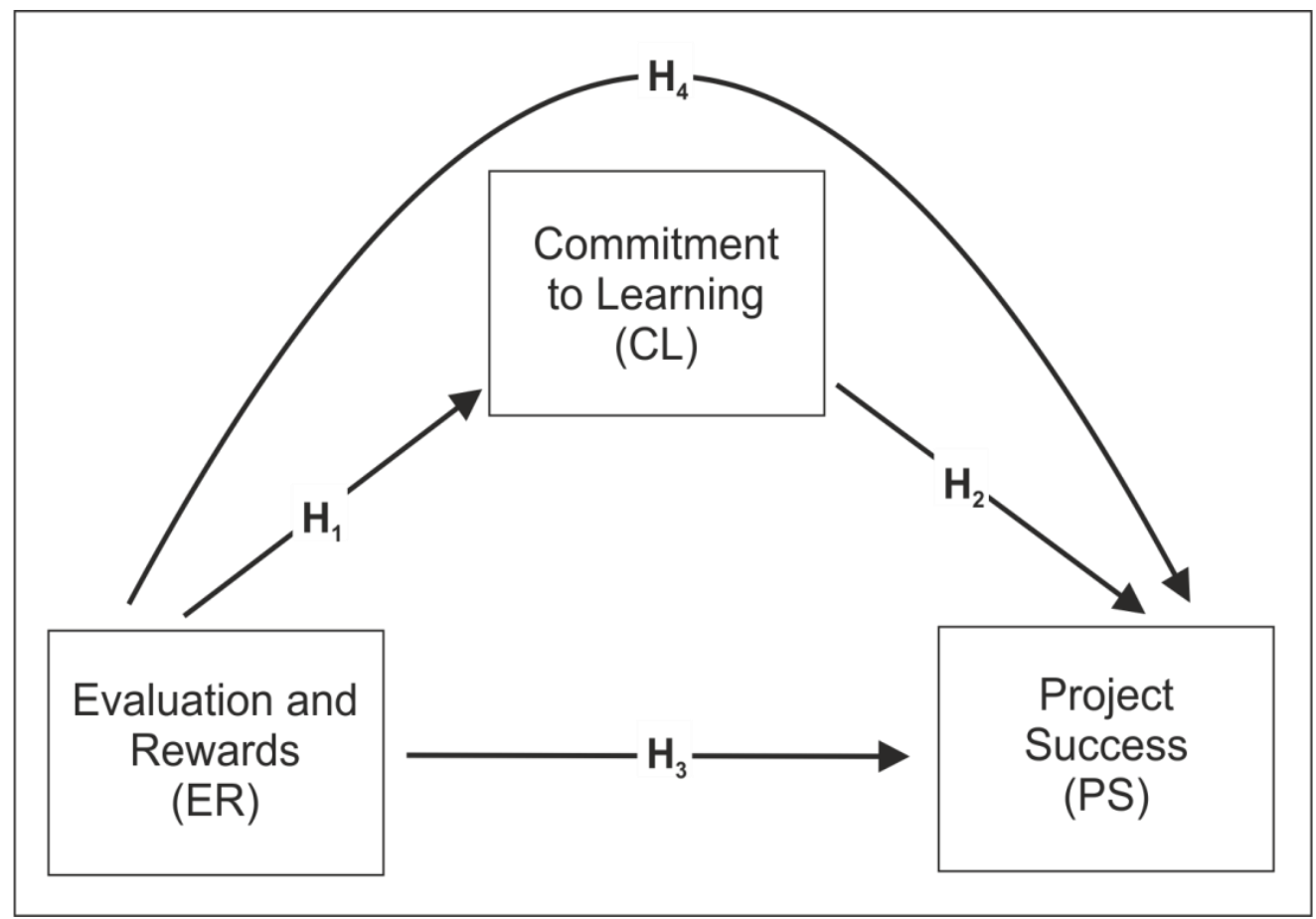

Figure 1. Conceptual Research Model

$\mathbf{H}_{1}$ : Evaluation and Rewards positively affects Commitment to Learning.

$\mathbf{H}_{2}$ : Commitment to Learning positively affects Project Success.

$\mathrm{H}_{3}$ : Evaluation and Rewards positively affects Project Success.

$\mathbf{H}_{4}$ : Commitment to Learning plays a mediator role in the relationshaip between Evaluation and Rewards and Project Success.

\section{RESEARCH METHODOLOGY}

This survey is a cross-sectional quantitative research. Five-point ordinal Likert scale was utilized. This scale is ranging from strongly disagrees to strongly agree was used. Firstly, the reliability and validity of the scales were examined. Afterwards, exploratory factor analysis and data purification, for confirming the validity of the constructs, structural equation modelling method was used. The Structural equations modelling are a confirmatory statistical method and can be used for determining the convergent validity of each construct (Civelek, Essentials of Structural Equation Modeling, 2018: 32). This method takes measurement errors into consideration (Byrne, 2010: 3). AMOS and SPSS statistics programs were used for the analyses. The mediator analyses were conducted according to the methodology suggested by Baron and Kenny (Baron \& Kenny, 1986: 1174).

\section{Measures and Sampling}

The scales taken from prior studies were utilized to measure the constucts. To measure Evaluation and Rewards, the scales adopted by Levi\&Slem (1995) were employed. Similarly, scales taken from Calantone et al. 
(2002) were used to measure Commitment to Learning. And finally, scales adopted from Cooper\&Kleinschmidt (1987) were used to measure Project Success. More than 250 having been distributed, 216 valid questionnaires were collected from 18 leading Logistics companies in Turkey by employing convenience voluntary response sampling method. Employees who work at R\&D departments of the companies make up the sample subjects of the study. 129 of the respondents are middle level and 87 are top level managers.

\section{Construct Validity and Reliability}

CFA was conducted in order to detect the convergent validity (Anderson \& Gerbing, 1988: 414). The confirmatory factor analysis (CFA) was carried out for the 17 prufied items following the process of principle component analysis. CFA model fit indicators reaches adequate degree: $\chi 2 / D F=1.710, C F I=0.917, I F I=0.919$, RMSEA $=0.093$. CMIN is The Likelihood Ratio Chi-Square analysis. This test refers to the conformity of the initial model and the acquired model. $\chi 2$ /DF ratio is below the threshold degree of 3 (Civelek, Yapısal Eşitlik Modellemesi Metodolojisi, 2018: 18). Additionally, other fit indices are near their recommended and acceptable thresholds. .

According to the outcomes of CFA analysis, as presented in Table 1, the standardized loads of each item are larger than 0.5 and significant. The outcomes confirmed the scales' convergent validity. For the detection of the discriminant validity, the AVE (Average Variance Extracted Value) were obtained and matched against the correlation values of the constructs in the same column. The values in the bracket, as presented in Table 2, show the square root of AVE value of each variable.

Table 1. Confirmatory Factor Analysis Results

\begin{tabular}{cccc}
\hline Variables & Items & $\begin{array}{c}\text { Standardized } \\
\text { Factor Loads }\end{array}$ & $\begin{array}{c}\text { Unstandardized } \\
\text { Factor Loads }\end{array}$ \\
\hline Evaluation and Rewards & ER0610 & 0.656 & 1 \\
(ER) & ER0509 & 0.858 & 1.301 \\
& ER0408 & 0.896 & 1.385 \\
Commitment to Learning & ER0307 & 0.874 & 1.439 \\
(CL) & ER0206 & 0.638 & 0.954 \\
\hline & CL0458 & 0.881 & 1 \\
& CL0357 & 0.838 & 0.899 \\
& CL0256 & 0.857 & 0.858 \\
& CL0155 & 0.808 & 0.875 \\
\hline Project Success & PS0841 & 0.755 & 1 \\
(PS) & PS0740 & 0.806 & 1.151 \\
& PS0639 & 0.783 & 1.227 \\
& PS0538 & 0.884 & 1.239 \\
& PS0437 & 0.872 & 1.203 \\
& PS0336 & 0.677 & 0.909 \\
\hline
\end{tabular}

$p<0.05$ for all items 
Additionally, the square roots of are beyond the correlation values in each column, which has been presented in Table 2 (Civelek, Yapısal Eşitlik Modellemesi Metodolojisi, 2018: 42). The reliability of each construct was also tested. The composite reliability and Cronbach $\alpha$ values are above the threshold degree (i.e. 0.7) (Fornell \& Larcker, 1981: 40). Table 2 presents the Composite reliabilities, Pearson correlation coefficients of the constructs, average variance extracted values, Cronbach $\alpha$ values, means, standard deviations.

Table 2. Descriptives Statictics, Correlations and Reliability

\begin{tabular}{lccc}
\hline \multicolumn{1}{c}{ Variables } & 1 & 2 & 3 \\
\hline 1.Evaluation and Rewards & $(.768)$ & & \\
2.Commitment to Learning & $.737^{*}$ & $(.602)$ & \\
3.Project Success & $.410^{*}$ & $.517^{*}$ & $(.733)$ \\
\hline Composite reliability & .892 & .910 & .932 \\
\hline Average variance ext. & .628 & .716 & .631 \\
\hline Cronbach $\alpha$ & .886 & .908 & .929 \\
\hline Mean & 3.12 & 3.53 & 3.27 \\
\hline Standard Deviation & 0.89 & 0.84 & 0.62 \\
\hline p $<0.01$ & & &
\end{tabular}

Note: Values in the bracket indicate the square root of AVEs.

\section{Test of Hypotheses}

Research model has been tested employing CB-SEM (Covariance Based Structural Equation Modelling). The default estimation method of CB-SEM is maximum likelihood. The evaluation of the goodness-of-fit indices of the model was also performed. These fit indices divided two parts as absolute and relative indices. The absolute goodness of fit indices are the root mean square error of approximation (RMSEA) and the $\chi 2$ goodness of fit values. The relative goodness of fit indices is the comparative fit index (CFI) and the incremental fit index (IFI). As Figure 2 shows, fit indices indicate satisfactory model fit. $\chi 2 / D F$ value is 1.788 and remains within the threshold levels (i.e. between 0 and 2). CFI and IFI are 0.907 and 0.910 , respectively. RMSEA is 0.098. The results determine that the model has adequate fit (Civelek, Yapısal Eşitlik Modellemesi Metodolojisi, 2018). As presented in Table 3, $\mathrm{H}_{1}, \mathrm{H}_{2}, \mathrm{H}_{3}$ and $\mathrm{H}_{4}$ are supported. These results of the tests indicate a positive and significant relationship between Evaluation and Rewards and Commitment to Learning, between Commitment to Learning and Product Success. 


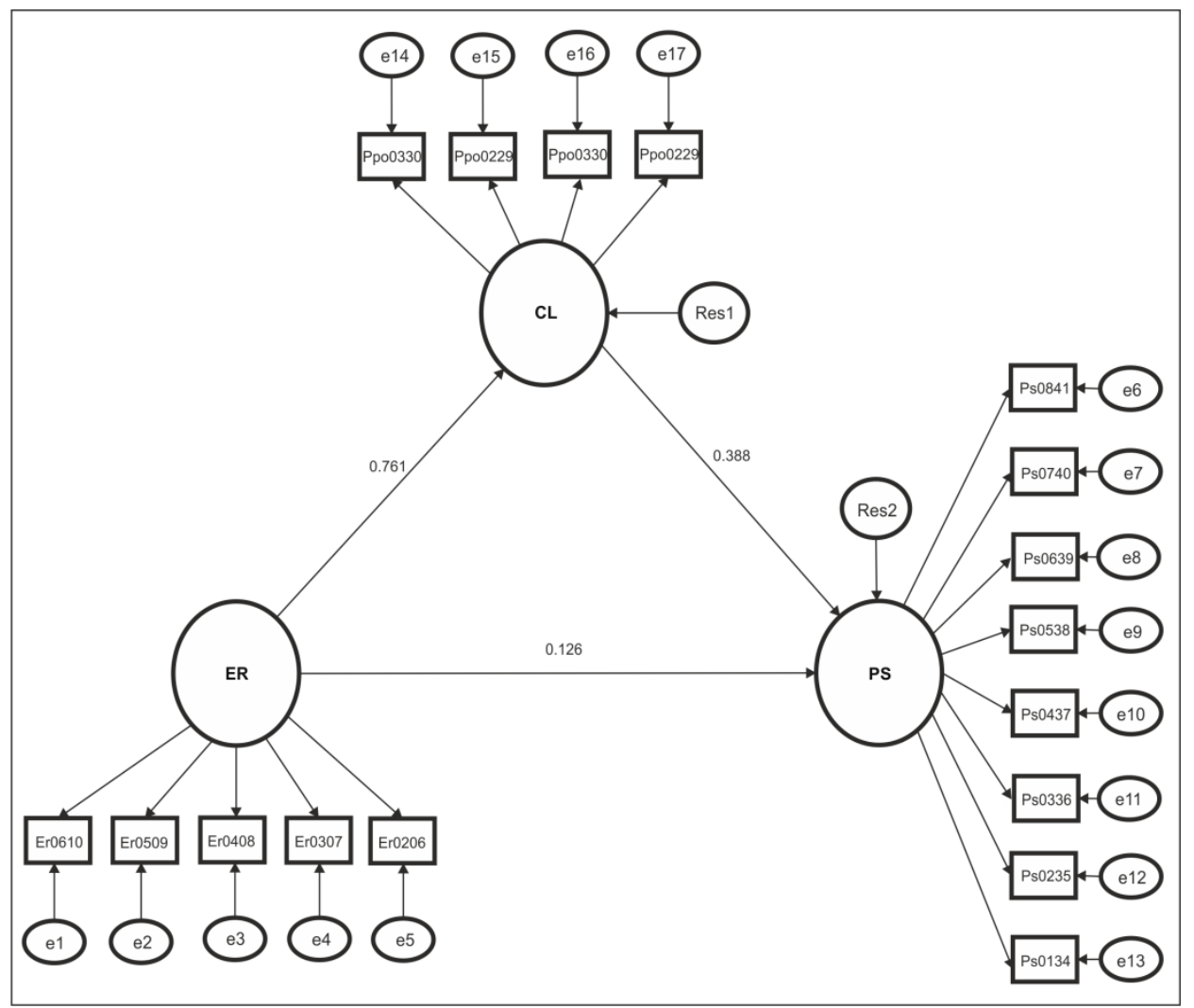

Note: $\chi 2 / D F=1.788, C F I=0.907, \mathrm{IFI}=0.910, \mathrm{RMSEA}=0.098$

Figure 2. Results of SEM Analysis of Model 3

The mediator analyses were performed by utilizing Baron and Kenny method (Baron \& Kenny, 1986). Tis method firstly requires correlation coefficients among the variables should be significant (Baron \& Kenny, 1986). Correlation coefficients are found significant as shown in the Table 2. Subsequently, below 3 models has been developed in order to test the hypotheses:

Model 1: PS $=\beta 0+\beta 1 . E R+€$

Model 2: $C L=\beta 0+\beta 2 . E R+€$

Model 3: $P S=\beta 0+\beta 1 . E R+\beta 2 . C L+€$

Table 3. Hypotheses Test Results

\begin{tabular}{|c|c|c|c|}
\hline Relationships & Model 1 & Model 2 & Model 3 \\
\hline Evaluation and Rewards (ER) $\rightarrow$ Project Success (PS) & $0.416^{*}$ & & 0.126 \\
\hline Evaluation and Rewards (ER) $\rightarrow$ Commitment to Learn $(\mathrm{CL})$ & & $0.715^{*}$ & \\
\hline Commitment to Learning (CL) $\rightarrow$ Project Success (PS) & & & $0.388 *$ \\
\hline
\end{tabular}

Note: Path coefficients are standardized

$* p<0.01$

$\mathrm{H}_{4}$ is supported as demonstrated in Table 3. This is because after $\mathrm{CL}$ was included into the model, the relationship between ER and PS decreased considerably and turned out to be insignificant. Based on the results, it can be stated that $\mathrm{CL}$ mediates the relationship between ER and PS. Following the inclusion of all the 
constructs into the model and considering the measurement errors, relationships yielded the results which have been presented in Figure 2.

\section{CONCLUSION}

This research can provide important contribution to the extant literature by attesting the relationship among Evaluation and Rewards (ER), Commitment to Learning (CL) and Project Success (PS). The findings of this research have proved that in the relationship between evaluation and rewards and project success, commitment to learning plays a mediator role. This result explains the distinctive nature of $R \& D$ teams. $R \& D$ teams are organic organizations where the bureaucracy is extremely limited, and members are gathered for a specific task and disband after the task is completed. Relations in bureaucratic organizational structures are not encountered in these teams. The criteria that affect performance in bureaucratic structures are different in adhocratic structures. The most important reason for this difference is that the members of the R\&D teams with adhocratic structure have a high level of professional and academic dexterity. Additionally, the members of these teams have a direct impact on the success of the project by reflecting their creative characteristics on team performance. It is not always appropriate to use rational methods when motivating a team. The result of this study exactly confirms this argument. Evaluation and Rewards, a dimension of teamwork in the literature, directly affect the success of a project. If this is an R \& D team, team members must be committed to learning in order for Evaluation and Rewards to affect project success. In R \& D teams, team members' commitment to learning is critical to the impact of reward and evaluation on project success. Therefore, the leaders who will lead these teams need to consider the nature of an adhocratic organization while taking into account the factors that will influence team success.

\section{ETHICAL TEXT}

In this article, journal writing rules, publishing principles, research and publishing ethics rules, journal ethics rules are followed. Responsibility belongs to the author $(\mathrm{s})$ for any violations related to the article.

\section{REFERENCES}

Akgün, A.E, Lynn G.S. \& Yılmaz C. (2005). "Learning Process in New Product Development Teams and Effects on Product Success: A Socio-Cognitive Perspective." Industrial Marketing Management, 35, 210-224.

Anderson, J. \& Gerbing, D. (1988). "Structural Equation Modelling in Practice: A Review and Recommended Two-Step Approach." Psychological Bulletin, 103(3), 411-423.

Baron, R., \& Kenny, D. (1986). “The Moderator - Mediator Variable distinction in Social Psychological Research: Conceptual, Strategic and Statistical Consideration. The Moderator - Mediator Variable Distinction in Social Psychological Research." Journal of Personality and Social Psychology, 1173-1182.

Byrne, B. M. (2010). Structural Equation Modeling with AMOS. New York: Routledge Taylor \& Francis Group. 
Calantone, R.J., Cavusgil S.T. \& Zhao, Y. (2002). “Learning Orientation, Firm Innovation Capability and Firm Performance." Industrial Marketing Management, 31 (6), 515-524.

Christensen, C., Raynor, M., Dy, J. \& Gregersen, H. (2011). Disruptive Innovation: The Christensen Collection (The Innovator's Dilemma, The Innovator's Solution, The Innovator's DNA, and Harvard Business Review Article "How Will You Measure Your Life?"). Boston: Harvard Business Review Press.

Civelek, M. E. (2018). Essentials of Structural Equation Modeling. Lincoln: University of Nebraska Lincoln-Zea Books.

Civelek, M. E. (2018). Yapısal Eşitlik Modellemesi Metodolojisi. İstanbul: Beta.

Cooke-Davies, T. (2002). "The Real Success Factors on Projects." International Journal of Project Management, 20 (3) 185-190.

Cooper, R. G. \& Kleinschmidt, E. (1987). "Success Factors in Product Innovation." Industrial Marketing Management, 16, $215-223$.

Çemberci, M. (2012). “Örgütsel Öğrenmenin Ar-Ge Takımlarının Performansı Üzerine Etkileri.” Journal of Academic Studies, 96 (57), 77-94.

De Wit, A. (1988). "Measurement of Project Success." International Journal of Project Management, 6(3), $164-$ 170.

Fornell, C. \& Larcker, D. (1981). “Evaluating Structural Equation Models with Unobservable Variables and Measurement Error." Journal of Marketing Research, 18(1), 39-50.

Grant, R. (1996). "Toward a Knowledge-Based Theory of the Firm." Strategic Management Journal, 17, 109122.

Hirschhorn, L. (1991). Managing in the New Team Environment. Addison-Wesley, Reading, MA, 101-119.

Howsawi, E., Eager, D., Bagia R. \& Niebecker, K. (2014). “The four-Level Project Success Framework: Application and Assessment." Organisational Project Management, 1 (1) 1-15.

Jugdev, K. \& Müller, R. (2005). “A Retrospective Look at Our Evolving Understanding of Project Success." Project Management Journal, 36 (4) 19-31.

Ika, L.A. (2009). “Project Success as a Topic in Project Management Journals.” Project Management Journal, 40 (4) 6-19.

Katzenbach, J. \& Smith, D. (1993). The Discipline of Teams. Harvard Business Review, 71(2), pp. 111-120.

Kerzner, H.R. (2011). Project Management Metrics, KPIs, and Dashboards: A Guide to Measuring and Monitoring Project Performance, John Wiley \& Sons, New Jersey.

Lawler, E. (1986). High Involvement Management. Jossey-Bass, San Francisco, CA.

Levi, D. \& Slem, C. (1995). "Team Work in R\&D Organizations: The Characteristics of Successful Teams." International Journal of Industrial Ergonomics, 16, pp. 29-42.

McLeod, L., Doolin, B. \& MacDonell, S.G. (2012). “A Perspective-Based Understanding of Project Success." Project Management Journal. 43 (5), 68-86.

Miller, D.B. (1986). Managing Professionals in Research and Development. The Jossey Bass (Management Series). California. 
Moorman, C. (1995). “Organizational Market Information Processes: Culture Antecedents and New Product Outcomes." Journal of Marketing Research, 32. 318-335.

Moorman, C. \& Miner A.S. (1998). “Organizational Improvisation and Organizational Memory." Academy Management Review, 23(4), 698-723.

Moorman, C. \& Miner A.S. (1998). "The Convergence of Planning and Execution: Improvisation in New Product Pevelopment." Journal of Marketing, 1-20.

O'Dell, C. (1989). “Team Play, Team Pay - New Ways of Keeping Score.” Across the Board, 26(11), 38-45.

Orsburn, J., Moran, L., Musselwhite, E., Zenger, J. \& Perrin, C. (1990). Self-Directed Work Teams: The New American Challenge. Business One Irwin, Homewood, IL.

Shenhar, A..J. \& Dvir, D. (2007). “Project Management Research - The Challenge and Opportunity." Project management journal, 38 (2) 93-99.

Thomas, J. \& Mullaly, M. (2014). "Researching the Value of Project Management, Project Management Institute, 2008 according to F.A. Mir, A.H. Pinnington, Exploring the Value of Project Management: Linking Project Management Performance and Project Success." International Journal of Project Management, 32(2), 202-217.

Zhang, Z., Shen , Z., Zhang, J. \& Zhang, R. (2015). “Informatics and Service Science." Proceedings of 4th International Conference on Logistics, Berlin: Springer. 